\author{
V.I. Mandzyuk ${ }^{1}$, I.F. Mironyuk ${ }^{1}$, Yu.O. Kyluk ${ }^{2}$
}

\title{
Structure-Morphological and Electroconductive Properties of Carbon Materials Based on Saccharose and Citric Acid
}

\author{
${ }^{I}$ Vasyl Stefanyk Precarpathian National University, Ivano-Frankivsk, Ukraine, volodymyr.mandzyuk@pnu.edu.ua \\ ${ }^{2}$ Ivan Franko National University of Lviv, Lviv, Ukraine, Yurij.Kyluk@lnu.edu.ua
}

\begin{abstract}
The article explores the effect of citric acid as a pore-forming agent on the structure, morphology and electroconductive properties of porous carbon materials (PCMs) obtained from carbon precursor (saccharose) using the methods of small-angle X-ray scattering, low-temperature porometry and impedance spectroscopy. It was found that the volumetric fractal structure is formed in the samples, and the fractal dimension $D_{v}$ decreases from 2.15 to 1.91 with the addition of citric acid due to surface loosening. It was set that the use of $20 \mathrm{wt}$ \% of citric acid causes the most effective modification of the porous structure of the material, i.e. an increase in specific surface area of 1.35 times, total pore volume of 1.14 times and a significant development of micro- and mesoporosity. It is shown that the use of citric acid as a pore-forming agent leads to an increase in the specific electrical conductivity of PCMs almost 5 times.

Keywords: porous carbon material, fractal structure, porous structure, specific surface area, pore size distribution, specific electrical conductivity.
\end{abstract}

Received 20 August 2020; Accepted 15 September 2020.

\section{Introduction}

Porous carbon materials (PCMs) are widely used for many applications in various industrial or domestic domains: as adsorbents for air and water purification, filter production [1-3], as electrodes for lithium power sources, supercapacitors, fuel cells in electrochemistry [4-6], as carriers of catalysts [7, 8]. Physical and thermochemical activation methods $[9,10]$, pore-forming reagents $[11,12]$ and exo- and endotemplates [13-15] are used to provide PCMs with the necessary physicochemical properties, the desired pore size distribution (PSD) and pore ratio. One of the simplest ways to modify the porous structure is to use organic acids in combination with carbon precursors, which in the process of thermochemical treatment have the ability to pass into the liquid phase (melt), which facilitates the structural ordering of graphene planes, nanosized graphite crystals and larger in size carbon clusters. Given this, it is interesting to combine citric acid as a poreforming agent and saccharose as a carbon precursor, as their melting points differ slightly $\left(153^{\circ} \mathrm{C}\right.$ for citric acid
[16] and $197^{\circ} \mathrm{C}$ for saccharose [17]). Therefore, the aim of this work is to study the structural-morphological and electrically conductive properties of PCMs obtained by thermochemical treatment of saccharose with citric acid.

\section{Experimental}

The initial sample PCM- 0 of carbonized material was obtained by thermolytic decomposition of saccharose $\left(\mathrm{C}_{12} \mathrm{H}_{22} \mathrm{O}_{12}\right)$ at $400^{\circ} \mathrm{C}$. The resulting material was activated at $800^{\circ} \mathrm{C}$ by annealing for $30 \mathrm{~min}$ in a ceramic container at restricted access of atmospheric air.

To modify the porous structure of carbon material $20 \mathrm{wt} . \%$ and $40 \mathrm{wt} . \%$ of citric acid was mixed with an aqueous solution of saccharose. Than the resulting solution was caramelized at $250^{\circ} \mathrm{C}$ and carbonized at $800^{\circ} \mathrm{C}$. The obtained samples were denoted as PCM-2 and PCM-4, respectively.

The small-angle X-ray scattering (SAXS) method was used to determine the structural parameters of the studied materials. This method is widely used to study the structural inhomogeneities of nanometric scale in 
dispersed systems, including porous materials [17, 18]. The measurements of SAXS-spectra were performed on $\mathrm{X}$-ray diffractometer in $\mathrm{Cu}-\mathrm{K} \alpha$ radiation $(\lambda=1.5418 \AA \AA)$, monochromatized by the reflection from the (200) plane of LiF monocrystal in the mode of passing of X-ray radiation beam through the standard. Primary and scattered beam collimators were used to limit parasitic scattering from monocrystal-monochromator and input slits, and to reduce the background scattering intensity. The use of a collimation system allows the measurement of SAXS-spectra, starting with $s=0.015 \AA^{-1}$ (where $s=\frac{4 \pi}{\lambda} \sin \theta$ is a wave vector, $\theta$ is a half of the scattering angle). A gap of $0.1 \mathrm{~mm}$ was set before the detector, which corresponds to the spatial separation of the detector $\Delta(2 \theta)_{d}=0.02^{\circ}$. The scattering was recorded in a scan mode in $0.05^{\circ}$ increments with an exposure time $\tau=125 \mathrm{~s}$. In the region of the smallest scattering angles, a primary beam, weakened by absorption in the sample, is superimposed on the scattered radiation. To exclude the effect of the primary beam on the scattering intensity, the following ratio was used:

$$
I^{*}(2 \theta)=I_{\exp }(2 \theta)-T \cdot I_{0}(2 \theta),
$$

where $I^{*}(2 \theta)$ is real scattering intensity, $I_{\exp }(2 \theta)$ is experimental scattering intensity, $I_{0}(2 \theta)$ is the intensity distribution of the primary beam, $T=\frac{I_{\exp }(0)}{I_{0}(0)}$ is transmission coefficient (the fraction of the intensity of the primary beam passing through the sample at the zero position of the detector). A collimation correction in the scattering intensity curves was made to the height of the detector receiving gap.

The structural adsorption characteristics of materials (degassed at $180^{\circ} \mathrm{C}$ for $24 \mathrm{~h}$ ) have been determined using the nitrogen adsorption-desorption isotherms recorded at 77.4 K using a Quantachrome Autosorb Nova 2200e adsorption analyzer.

A capacitor system with two blocking copper electrodes, between which the test standard is placed, was used to study the conductive characteristics of the materials. Impedance hodographs $Z^{\prime \prime}=\mathrm{f}\left(Z^{\prime}\right)$, where $Z^{\prime}$ and $Z^{\prime \prime}$ are the real and imaginary components of the complex resistance of the system, were carried out using a Metrohm Autolab FRA-2 (Frequency Response Analyzer, Holland) at $10^{-2}-10^{5} \mathrm{~Hz}$ and sinusoidal voltage amplitude of $10 \mathrm{mV}$.

\section{Results and discussion}

As follows from the SAXS-data a power dependence of the intensity is observed on the intensity curves of the studied materials in the range $\left(s_{1}, s_{2}\right)$ (Fig. 1). The $n$ value is in the interval $1<n<3$, which indicates the fractal distribution of inhomogeneities. A volume fractal structure with dimension $D_{v}=n$ consists of carbon clusters is formed in the samples. The use of citric acid at the material synthesis results in a decreasing in the fractal dimension due to the loosening of the structure.

The distribution of pore inertia radii is analyzed within the model of polydisperse spheres. For this purpose, histograms of pore distribution were constructed (Fig. 2).

The analysis of the obtained results shows, the characteristics of the porous structure of the samples change significantly depending on the content of citric acid in the initial mixture. Thus, in the sample PCM-0, the main contribution to the porous volume is made by macropores with an inertia radius $r_{g} \approx 37 \mathrm{~nm}$ $\left(m_{k} \approx 46 \%\right)$. The formation of micropores with a radius $r_{g} \approx 0.83 \mathrm{~nm}$ is also observed, but their volume fraction is much smaller $\left(m_{k} \approx 6 \%\right)$.

In the sample PCM-2 there is a decrease in the content of macropores up to $36 \%$ while increasing the proportion of micropores with a radius $r_{g} \approx 0.92 \mathrm{~nm}$ $\left(m_{k} \approx 11 \%\right)$. The remaining porous volume of the material $\left(m_{k} \approx 53 \%\right)$ is mesopores with a maximum close to $r_{g} \approx 24 \mathrm{~nm}$.

More significant changes in the characteristics of the porous structure are observed in the sample PCM-4. In this case, the largest contribution to the formation of the porous volume is made by mesopores with a radius $r_{g} \approx 20 \mathrm{~nm} \quad\left(m_{k} \approx 29 \%\right)$. The volume fraction of macropores and their radius decrease $\left(m_{k} \approx 25 \%\right.$, $r_{g} \approx 320 \mathrm{~nm}$ ). In addition, there is a slight increase in the content of micropores with a radius $r_{g} \approx 1 \mathrm{~nm}$ $\left(m_{k} \approx 14 \%\right)$.

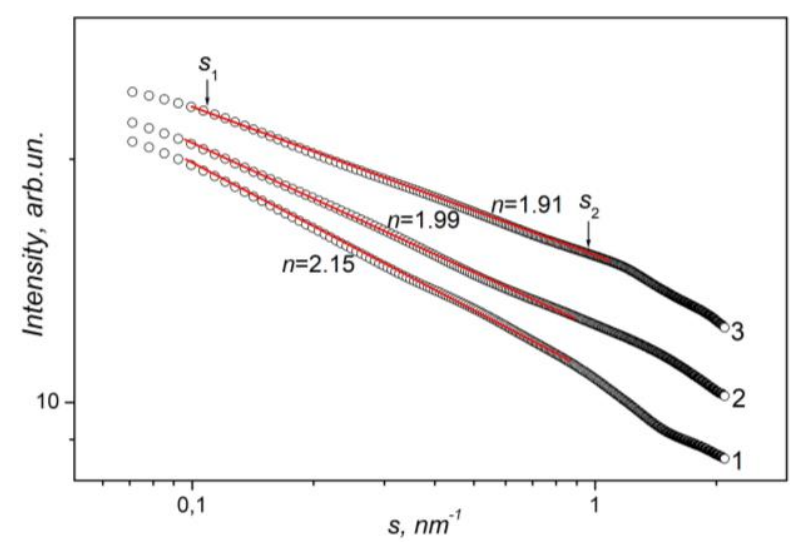

Fig. 1. SAXS-curves for samples PCM-0 (curve 1), PCM-2 (2), and PCM-4 (3).

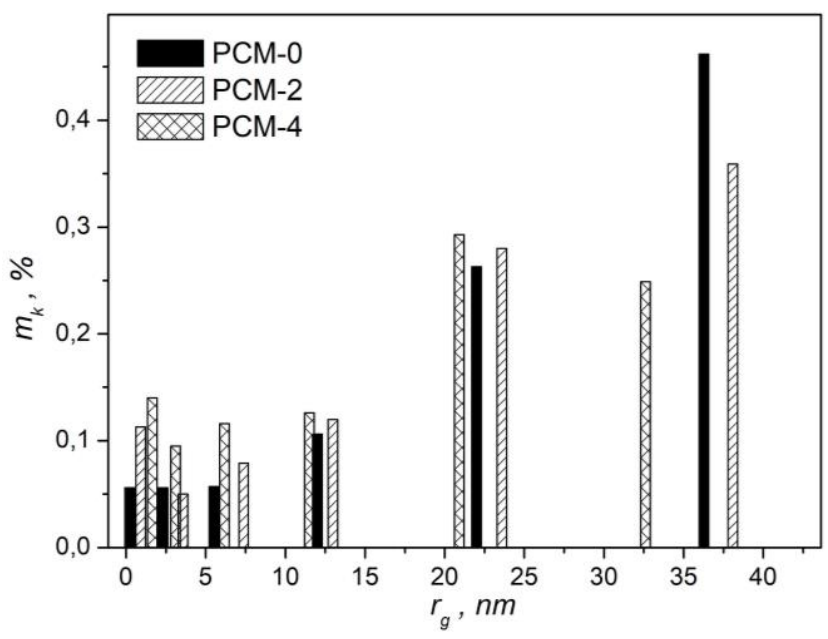

Fig. 2. Histograms of pore distribution $\left(m_{k}-\right.$ volume fraction of pores, $r_{g}$ - pore inertia radii). 


\section{V.I. Mandzyuk, I.F. Mironyuk, Yu.O. Kyluk}

The peculiarity of the SAXS-method in the study of the structure of porous materials is that it provides information about the closed and open pores in the material. Given the scope of PCMs, it is clear that the open surface will play a decisive role. In this case, it is necessary to know the value of the surface available for molecules or ions, i.e. the value of the open porosity of the material.

The method of low-temperature porometry, which is based on obtaining adsorption / desorption isotherms, on the basis of which further calculations can be performed, is quite useful for obtaining this information. Nitrogen adsorption / desorption isotherms (Fig. 3) for all samples are similar and type I according to the IUPAC classification [19], which is characteristic of microporous solids with a relatively small external surface. All isotherms are characterized by the deviation of the adsorption and desorption branches, especially in the low pressure range, which is called low pressure hysteresis. According to [19] the main reasons for this behavior can be: irreversible retention of adsorbate molecules in the pores, the size of which is close to their size; irreversible chemical interaction of the adsorbate with the adsorbent; swelling of the spatial macromolecular framework of the adsorbent; a complex system of interconnected pores.

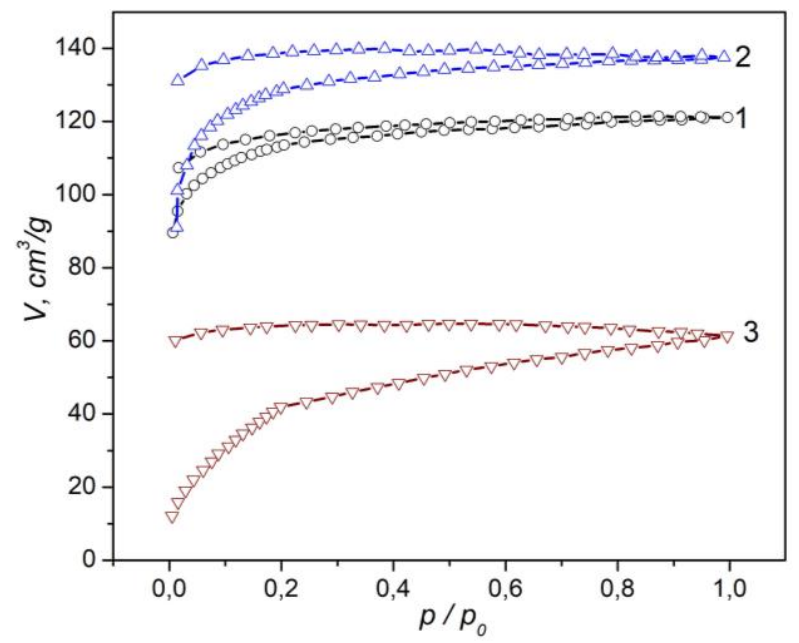

Fig. 3. Sorption isotherms for PCM-0 (curve 1), PCM-2 (2), and PCM-4 (3).

A multipoint BET (Brubauer-Emmett-Teller) method was used to determine the specific surface $S$ of PCMs [19]. This method is based on the equation:

$$
\frac{1}{W\left(p_{0} / p\right)-1}=\frac{1}{W_{m} \cdot C}+\frac{C-1}{W_{m} \cdot C}\left(p_{0} / p\right),
$$

where $W$ is mass of gas adsorbed at relative pressure $p / p_{0}, W_{m}$ is mass of adsorbed gas forming a monolayer covering the entire surface, $C$ is BET constant, which refers to the adsorption energy in the first adsorption layer (its value is an indicator of the magnitude of the adsorbent-adsorbate interaction). The construction of this dependence in the coordinates $\frac{1}{W\left(p_{0} / p\right)-1}=f\left(p_{0} / p\right)$ makes it possible to approximate the experimental data by a straight line in the range of relative pressures $p / p_{0}=0.05 \div 0.35$ and to calculate the value of the specific surface $S$ (Table 1).

According to Table 1, modification of the initial precursor by citric acid leads to a non-monotonic change in the specific surface of the materials. The greatest changes are the specific surface of the PCM when adding to the initial precursor $20 \mathrm{wt}$. \% of pore-forming agent, i.e. its value increases more than 3.5 times. However, when adding $40 \mathrm{wt}$. $\%$ of the pore-forming agent, its value decreases by 2.3 times.

Given the SAXS-data, according to which the porous structure of materials is formed by micro-, meso-, and macropores, we use the $t$-method, which will determine the size of the external surface of the pores $S_{\text {ext }}$ (this includes the surface of meso- and macropores), and the formula $S_{\text {micro }}=S-S_{\text {ext }}$ to calculate a micropore surface values. The $t$-method is based on the fact that the initial adsorption isotherm is rearranged in the range of relative pressures $p / p_{0}=0.2 \div 0.5$ as a function of a new variable $t$, which is called the statistical thickness of the adsorption film and is determined by the expression:

$$
t=\sigma \cdot \frac{W}{W_{m}},
$$

where $\sigma$ is a monomolecular thickness of the adsorption film, which is $0.354 \mathrm{~nm}$ for nitrogen at $T=77 \mathrm{~K}$.

For microporous materials in the presence of mesopores, the dependence of the volume of adsorbed gas $V$ on $t$ is a straight line, the extrapolation of which to the intersection with the $V$-axis makes it possible to determine the volume of micropores, and the tangent of the angle to calculate the external surface $S_{\text {ext }}$ (Table 1).

The data obtained shows (Table 1), the specific surface area occupied by micropores is the largest for the sample PCM-2. Their content is $91 \%$, which indicates the effective use of citric acid as a pore-forming agent. For the sample PCM-4, there is a slight redistribution between the micro- and mesopores in favor of the latter compared to the initial material.

It is obvious that, the parameters that characterize the pore volume of PCMs will undergo changes when adding a pore-forming agent. The total pore volume $V$ of the materials was calculated under the condition $p / p_{0} \approx 1$. Its

Table 1

Parameters of porous structure of carbon materials

\begin{tabular}{|c|c|c|c|c|c|c|c|c|}
\hline Sample & $\begin{array}{c}S, \\
\mathrm{~m}^{2} / \mathrm{g}\end{array}$ & $\begin{array}{c}S_{\text {micro }}, \\
\mathrm{m}^{2} / \mathrm{g}\end{array}$ & $\begin{array}{c}S_{\text {ext }}, \\
\mathrm{m}^{2} / \mathrm{g}\end{array}$ & $\begin{array}{c}S_{\text {microl }} / S, \\
\%\end{array}$ & $V, \mathrm{~cm}^{3} / \mathrm{g}$ & $\begin{array}{c}V_{\text {micro }}, \\
\mathrm{cm}^{3} / \mathrm{g}\end{array}$ & $\begin{array}{c}V_{\text {meso }}, \\
\mathrm{cm}^{3} / \mathrm{g}\end{array}$ & $V_{\text {micro }} / V, \%$ \\
\hline PCM-0 & 356 & 204 & 152 & 57 & 0.187 & 0.092 & 0.095 & 49 \\
\hline PCM-2 & 479 & 435 & 44 & 91 & 0.213 & 0.184 & 0.029 & 86 \\
\hline PCM-4 & 152 & 82 & 70 & 54 & 0.095 & 0.035 & 0.060 & 37 \\
\hline
\end{tabular}


value changes similarly to the change in the specific surface $S$ with increasing concentration of the poreforming agent (Table 1). The volume of $V_{\text {micro }}$ micropores (as well as mesopores $V_{\text {meso }}$ ), the value of which was calculated by the $t$-method, changes in a similar way.

Let's analyze what changes the PSD of materials undergoes when adding a pore-forming agent. To determine this distribution, preference is given to the desorption isotherm, which represents a lower relative pressure for the same gas volume, i.e. less energy is used. Thus, the desorption isotherm is closer to the true thermodynamic equilibrium [19].

Given that the samples contain both micro- and mesopores, it is necessary to use appropriate methods to determine the PSD. The BJH (Barret-Joyner-Halenda) method, which is based on the Kelvin equation [19]:

$$
\ln \left(\frac{p}{p_{0}}\right)=\frac{2 \gamma V_{L}}{R T r_{m}},
$$

(where $\gamma$ is surface tension of nitrogen at the boiling point, $V_{L}$ is molar volume of liquid nitrogen, $R$ is a gas constant, $r_{m}$ is pore radius), is quite common for determining the mesopore size distribution.

The results obtained shows that PSDs for samples PCM-0 and PCM-4 is characterized by a single intense maximum close to $3.5 \mathrm{~nm}$, while PSD for sample PCM-2 is characterized by a number of maxima around $4.3 ; 6.8$; 9.1 and $30.8 \mathrm{~nm}$ (Fig. 4). Thus, the use of $20 \mathrm{wt}$. \% of the pore-forming agent to obtain PCM leads not only to a significant increase in the specific surface area and volume of the sample, but also to significant changes in the PSD, primarily mesoporous structure.

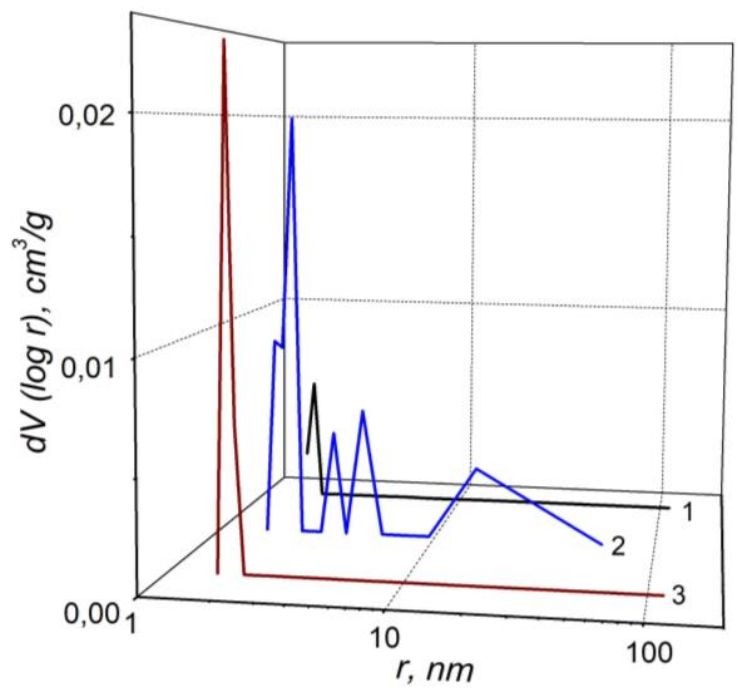

Fig. 4. The mesopore size distribution for PCM-0 (curve 1), PCM-2 (2), and PCM-4 (3) according BJH-method.

To estimate what changes the microporous structure of PCMs undergoes at addition of a pore-forming agent one can use the NLDFT (nonlocal density functional theory) method in approximation of slit-shaped pores. This method is based on a quantum mechanical approach and uses to calculate the fundamental molecular parameters that characterize the gas-gas (gas-liquid) and gas-solid interaction [19]. As follows from the results, presented in the form of a set of histograms (Fig. 5), for samples PCM-2 and PCM-4 there are intense maxima of
$0.211 \mathrm{~cm}^{3} / \mathrm{g}$ and $0.096 \mathrm{~cm}^{3} / \mathrm{g}$, respectively, around $0.67 \mathrm{~nm}$ in PSDs. For the sample PCM-0, maximum is more blurred close to $0.58 \mathrm{~nm}$.

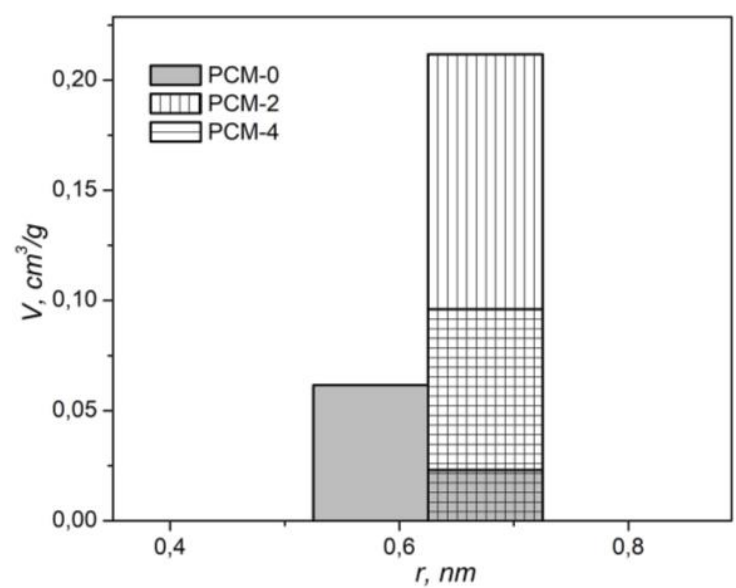

Fig. 5. Micropore size distribution of PCMs according NLDFT-method.

The adding a pore-forming agent to the initial precursor not only changes structural and morphological parameters of material obtained, but also affects its electroconductive properties. According to impedance spectroscopy, such a modification practically does not change the shape of the impedance hodograph $Z^{\prime \prime}=\mathrm{f}\left(Z^{\prime}\right)$ of the initial sample, but leads only to quantitative changes in the real $Z^{\prime}$ and imaginary $Z^{\prime \prime}$ parts of the complex resistance of the system (Fig. 6).

Taking into account the geometrical parameters of the samples, the specific values of resistances, electrical conductivities and frequency dependences of the electrical parameters were calculated according to the equations.

$$
\rho^{*}=\rho^{\prime}-j \rho^{\prime \prime},
$$

where $\rho^{\prime}=Z^{\prime} A / d$ i $\rho^{\prime \prime}=Z^{\prime \prime} A / d, A$ and $d$ are the surface area of the electrode and the standard thickness, respectively.

The total conductivity of materials was determined by the formula $\sigma=\sqrt{\left(\sigma^{\prime}\right)^{2}+\left(\sigma^{\prime \prime}\right)^{2}}$, where $\sigma^{\prime}=\rho^{\prime} / M$, $\sigma^{\prime \prime}=\rho^{\prime \prime} / M, \quad M=\left|Z^{*}\right|^{2}(A / d)^{2}, \quad Z^{*}=\sqrt{\left(Z^{\prime}\right)^{2}+\left(Z^{\prime \prime}\right)^{2}}$ [20].

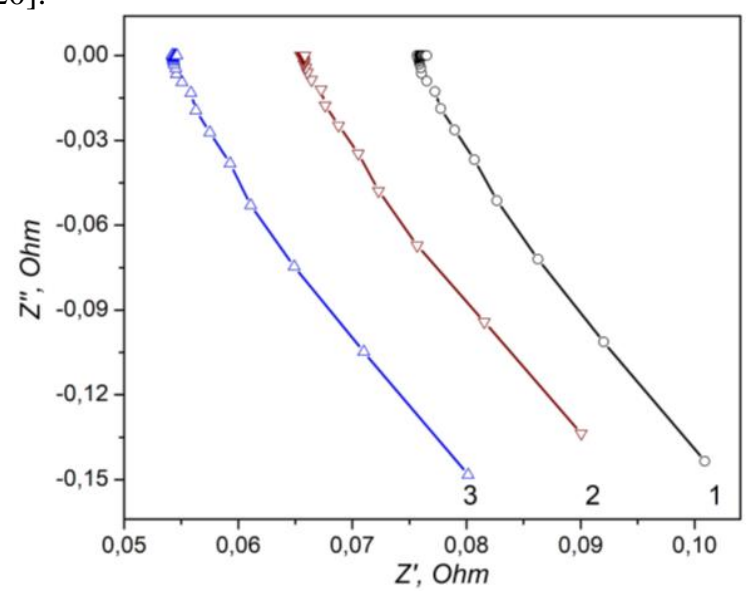

Fig. 6. The Nyquist diagrams for PCM-0 (curve 1), PCM-2 (2), and PCM-4 (3). 
Since the values of the real part of the electrical conductivity at frequencies less than $10^{3} \mathrm{~Hz}$ are about 2-3 orders of magnitude greater than the value of the imaginary one, the contribution of the latter to the total conductivity of PCM can be neglected. In this case, the frequency behavior of total conductivity will also be determined mainly by the frequency dependence of its real part (Fig. 7).

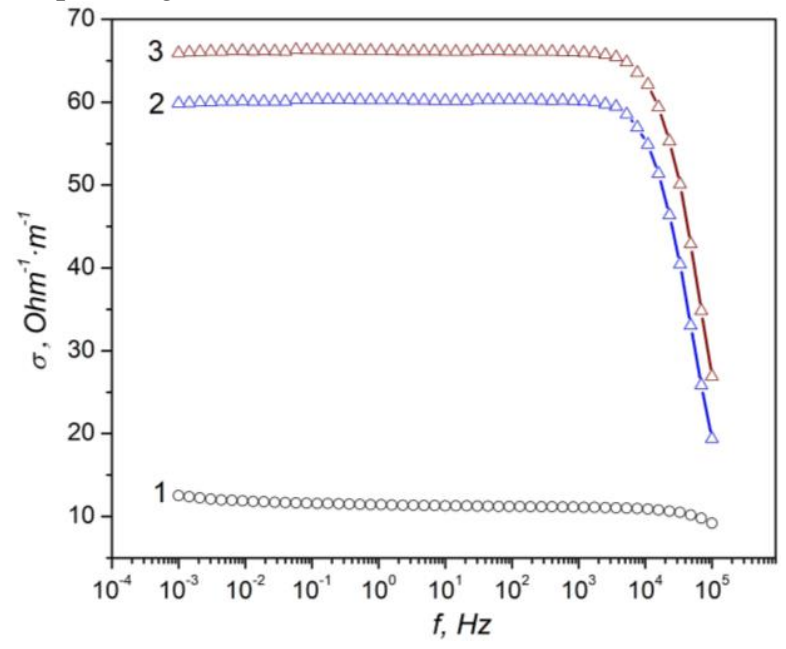

Fig. 7. Frequency dependence of total conductivity for PCM-0 (curve 1), PCM-2 (2), and PCM-4 (3).

Representation of frequency dependences of electrical conductivity in semi-logarithmic coordinates makes it possible to determine the value of the specific electrical conductivity of PCMs by extrapolating the experimental curve to its intersection with the $\sigma$-axis (a DC-output for $f \rightarrow 0$ ). The value of specific conductivity is about $13 \mathrm{Ohm}^{-1} \cdot \mathrm{m}^{-1}$ for the sample PCM-0, $60 \mathrm{Ohm}^{-1} \cdot \mathrm{m}^{-1}$ for PCM-2 and $66 \mathrm{Ohm}^{-1} \cdot \mathrm{m}^{-1}$ for PCM-4.
Despite the simultaneous increase in micro- and mesoporosity of the material, which interferes with electron transport, such an increase in conductivity is most likely due to the fact that citric acid contributes to the structural ordering of graphene planes at different stages of PCM obtaining (dehydration, melting, caramelization, carbonization).

\section{Conclusions}

It is shown that the use of citric acid as a poreforming agent at the synthesis of saccharose-derived PCMs allows to change in a wide range the structuralmorphological and electrically conductive properties of materials.

It was found that the structure of PCMs is formed by volume fractal clusters, the dimension of which decreases with increasing concentration of citric acid in the initial mixture due to the activating action of the latter.

It is set that the optimal concentration of citric acid is the value of $20 \mathrm{wt} . \%$, at which the greatest increase in the specific surface area, the total pore volume and a significant redistribution of pores in size are observed.

Mandzyuk V.I. - Doctor in Physics and Mathematics, Associate Professor, Associate Professor of Computer Engineering and Electronics Department;

Mironyuk I.F. - Professor, Doctor in Chemistry, Head of the Chemistry Department;

Kulyk Y.O. - PhD, Leading Engineer, Department of Metal Physics.

[1] G. Sriram, S. Supriya, M. Kurkuri, G. Hegde, Mater. Res. Express 7, 015605 (2020) (doi:10.1088/20531591/ab5f2c).

[2] Y. Yoon, S. Kim, K. Ahn, K. Ko, K.S. Kim, Environ. Tech. 37(6), 703 (2016) (doi:10.1080/09593330.2015.1078416).

[3] S.Y. Kim, Y.H. Yoon, K.S. Kim, Int. J. Environ. Sci. Technol. 13, 2189 (2016) (doi: 10.1007/s13762-0161046-8).

[4] B.K. Ostafiychuk, I.M. Budzulyak, B.I. Rachiy, R.P. Lisovsky, V.I. Mandzyuk, P.I. Kolkovsky, R.I. Merena, M.V. Berkeshchuk, L.V. Golovko, Journal of Nano- and Electronic Physics 9(5), 05001-1 (2017) (doi: 10.21272/jnep.9(5).05001).

[5] V.I. Mandzyuk, N.I. Nagirna, R.P. Lisovsky, Journal of Nano- and Electronic Physics 6(1), 01017-1 (2014).

[6] J. Wang, I. Senkovska, S. Kaskel, Q. Liu, Carbon 75, 372 (2014) (doi:10.1016/j.carbon.2014.04.016).

[7] I. Matos, M. Bernardo, I. Fonseca, Catalysis Today 285, 194 (2017) (doi:10.1016/j.cattod.2017.01.039).

[8] E. Lam, J.H.T. Luong, ACS Catal. 4(10), 3393 (2014) (doi:10.1021/cs5008393).

[9] A. Ahmadpour, D.D. Do, Carbon 34(4), 471 (1996) (doi: 10.1016/0008-6223(95)00204-9).

[10] B.K. Ostafiychuk, I.M. Budzulyak, B.I. Rachiy, V.M. Vashchynsky, V.I. Mandzyuk, R.P. Lisovsky, L.O. Shyyko, Nanoscale Research Letters 10(65), 1 (2015) (doi: 10.1186/s11671-015-0762-1).

[11] S.L. Revo, I.M. Budzulyak, B.I. Rachiy, M.M. Kuzishin, Surface Engineering and Applied Electrochemistry 49(1), 68 (2013) (doi:10.3103/s1068375513010122).

[12] B.K. Ostafiychuk, R.P. Lisovskiy, A-S.A.H. Zamil, B.I. Rachiy1, V.O. Kotsyubynsky, P.I. Kolkovsky, R.I. Merena, A.B. Hrubiak, Journal of Nano- and Electronic Physics 11(3), 03036-1 (2019) (doi:10.21272/jnep.11(3).03036).

[13] Y. Xia, Z. Yang, R. Mokaya, Nanoscale 2(5), 639 (2010) (doi:10.1039/b9nr00207c).

[14] N.D. Shcherban, V.G. Ilyin, Chemistry, Physics and Technology of Surface 6, 97 (2015) (doi:0.15407/hftp06.01.097). 
[15] V.I. Mandzyuk, I.F. Myronyuk, V.M. Sachko, I.M. Mykytyn, Surface Engineering and Applied Electrochemistry 56(1), 93 (2020) (doi:10.3103/S1068375520010123).

[16] Б.П. Никольский, Справочник химика (Химия, Ленинград, 1971).

[17] I.F. Myronyuk, V.I. Mandzyuk, V.M. Sachko, V.M. Gun'ko, Nanoscale Research Letters 11(508), 1 (2016) (doi:10.1186/s11671-016-1723-z).

[18] C.J. Gommes, T. Asset, J. Drnec, J. Appl. Cryst. 52(3), 507 (2019) (doi:10.1107/s1600576719003935).

[19] S.J. Gregg, K.S.W. Sing, Adsorption, surface area and porosity (Academic Press, London, 1982).

[20] M.H. Abdullah, A.N. Yusoff, J. Alloys Compounds 233, 129 (1996) (doi:10.1016/0925-8388(96)80044-2).

\section{В.І. Мандзюк ${ }^{1}$ І.Ф. Миронюк ${ }^{1}$ Ю.О. Кулик ${ }^{2}$}

\section{Структурно-морфологічні та електропровідні властивості вуглецевих матеріалів, отриманих на основі сахарози і лимонної кислоти}

\footnotetext{
${ }^{1}$ Прикарпатський національний університет імені Василя Стефаника, Івано-Франківськ, Україна, volodymyr.mandzyuk@pnu.edu.ua

${ }^{2}$ Львівський наиіональний університет імені Івана Франка, Львів, Украӥна, Yurij.Kyluk@lnu.еdи.иа

У роботі з використанням методів малокутового Х-променевого розсіяння, низькотемпературної порометрії та імпедансної спектроскопії досліджено вплив лимонної кислоти як пороутворювача на структуру, морфологію та електропровідні властивості пористих вуглецевих матеріалів (ПВМ), отриманих із вуглецевого прекурсору (сахарози). 3'ясовано, що в зразках формується об'ємна фрактальна структура, причому фрактальна розмірність $D_{v}$ зменшується від 2,15 до 1,91 при додаванні лимонної кислоти за рахунок розрихлення поверхні. Встановлено, що застосування 20 мас.\% лимонної кислоти зумовлює найбільш ефективну модифікацію пористої структури матеріалу - збільшення питомої поверхні в 1,35 рази, загального об'єму пор в 1,14 рази та значний розвиток мікро- і мезопористості. Показано, що використання лимонної кислоти як пороутворювача призводить до зростання питомої електропровідності ПВМ майже у 5 разів.

Ключові слова: пористий вуглецевий матеріал, фрактальна будова, пориста структура, питома поверхня, розподіл пор за розмірами, питома електропровідність.
} 